\title{
Perlindungan Konsumen Pangan Pada Negara Mayoritas Muslim Ditinjau dari Peraturan Pemerintah Nomor 69 Tahun 1999 Tentang Label Dan Iklan Pangan
}

\author{
Teddy Prima Anggriawan \\ Fakultas Hukum, Universitas Airlangga \\ J1. Dharmawangsa Dalam Selatan, Kec. Gubeng, Surabaya \\ teddyhukum@gmail.com
}

\begin{abstract}
Abstrak
Perkembangan teknologi pengolahan pangan khususnya pada makanan dan minuman yang begitu pesat membuat umat Islam perlu meningkatkan kewaspadaan dan menuntut kejelasan kehalalan setiap produk, demi ketenangan dalam mengkonsumsi dan mempergunakannya. Sebagai negara dengan mayoritas Muslim perlunya juga pengaturan mengenai label non halal, agar masyarakat lebih mendapat kepastian informasi terkait haknya sebagai konsumen produk halal. Adapun cara yang digunakan untuk mengambil hasil penelitian normatif agar menjadi lebih faktual dalam penjelasannya, maka diperlukan pendekatan hukum yang dilakukan dalam setiap pembahasannya. Sehingga peneliti mengambil bahasan Rekonstruksi Penormaan Label Sertifikasi Makanan dalam Upaya Perlindungan Konsumen Pada Negara Mayoritas Muslim
\end{abstract}

Kata kunci: Rekonstruksi Penormaan, label Halal, Perlindungan Konsumen

\begin{abstract}
The development of food processing technology, especially in food and beverages, is so rapid that Muslims need to increase their vigilance and demand clarity on the halalness of each product, for the sake of peace in consuming and using it. As a country with a Muslim majority, it is also necessary to regulate non-halal labels, so that the public can have more certainty of information regarding their rights as consumers of halal products. As for the method used to take normative research results in order to be more factual in their explanation, a legal approach is needed in each discussion. So the researchers took the discussion of Reconstruction of Food Certification Labels in Consumer Protection Efforts in Muslim Majority Countries
\end{abstract}

Keywords: Reconstruction of labeling, Halal label, Consumer Protection

\section{A. Pendahuluan}

Kemajuan teknologi yang didasarkan dari perkembangan ilmu pengetahuan berdampak pula pada perubahan perilaku dalam bermasyarakat yang sangat cepat, perubahan masyarakat tersebut dirasakan di beberapa wilayah kota-kota besar di Indonesia seperti pada perubahan gaya hidup dan kebutuhan yang harus dipenuhi. Dalam hal ini permintaan pasar atau yang disebut dengan konsumen juga berharap bahwa produk yang dibelinya berkualitas. Pada konsumen muslim produk halal menjadi pertimbangan utama untuk menentukan barang yang hendak dibeli tersebut layak atau tidak sesuai dengan kriterianya.

Penjelasan Undang-Undang Nomor 18 Tahun 2012 tentang Pangan menyatakan bahwa Pangan ${ }^{1}$ merupakan kebutuhan dasar manusia yang paling utama dan

1 Pangan adalah segala sesuatu yang berasal dari sumber hayati produk pertanian, perkebunan, kehutanan, peri-kanan, peter-nakan, perairan, dan air, baik yang diolah maupun tidak diolah, yang diperuntukkan sebagai ma-kanan atau minuman bagi konsumsi manusia, termasuk bahan tambahan 
pemenuhannya merupakan bagian dari hak asasi setiap rakyat Indonesia. Pangan harus senantiasa tersedia secara cukup, aman, bermutu, bergizi, dan beragam dengan harga yang terjangkau oleh daya beli masyarakat, serta tidak bertentangan dengan agama, keyakinan, dan budaya masyarakat. ${ }^{2}$ Mengkonsumsi produk halal menurut keyakinan agama (Islam) dan/atau demi kualitas hidup dan kehidupan, merupakan hak warga negara yang dijamin oleh Undang-Undang Dasar 1945, khususnya Undang-Undang Perlindungan Konsumen Nomor 8 Tahun 1999. ${ }^{3}$ Dan mengkonsumsi yang halal itu merupakan kewajiban bagi setiap Muslim. ${ }^{4}$

Kata halal berasal dari istilah bahasa arab dalam agama islam yang berarti "diizinkan" atau "boleh". Secara etimologi, halal berarti hal-hal yang boleh dan dapat dilakukan karena bebas atau tidak terikat dengan ketentuan-ketentuan yang melarangnya. ${ }^{5}$ Dalam kehidupan sehari-hari pemaknaan istilah halal dapat dimaknai bahwa makanan maupun minuman tersebut boleh dikonsumsi karena sudah sesuai dengan syariat islam.

Sesuai dengan perkembangan masyarakat pada era sekarang, perilaku masyarakat bergeser dari pemahaman mengenai terpenuhinya kebutuhan berkaitan dengan konsumsi ke produk yang sesuai dengan syariat islam, karena produk tersebut diyakini mengandung banyak kemanfaatan dan dianggap sebagai suatu kebaikan yang wajib dijalankan, hal tersebut didasarkan pada adanya keyakinan bahwa apabila mengkonsumsi dan memakai produk yang sesuai dengan syariat islam merupakan suatu perintah agama. Hal tersebut terdapat didalam Alqur'an surat Al Baqarah : 168 yang artinya :

"Hai sekalian manusia, makanlah yang halal lagi baik dari apa yang terdapat di bumi, dan janganlah kamu mengikuti langkah-langkah setan; karena sesungguhnya setan itu adalah musuh nyata bagimu."

Di dalam surat tersebut ayat 168 , adanya seruan kepada seluruh umat manusia, baik yang beragama islam maupun lainnya agar menikmati segala rejeki yang berasal dari

Pangan, bahan baku Pangan, dan ba-han lain yang digunakan dalam proses penyiapan, peng-olahan, dan/atau pembuatan makanan atau minuman (Pasal 1 angka 1 Undang-Undang nomor 18 Tahun 2012 tentang Pangan).

${ }^{2}$ Fathurrahman Djamil, "Kalau Banyak Lembaga Fatwa, Umat Bisa Bingung”, Jurnal Halal, No. 100 Th. XVI Ta-hun 2013, Jakarta: LPPOM MUI, hlm. 48-49

3 Amirsyah Tambunan, "Hak Konsumen dalam Perspektif UU No. 8 Tahun 1999", Jurnal Halal, No.101 Th. XVI Ta-hun 2013, Jakarta: LPPOM MUI, hlm. 16

4 Anton Apriyantono, "LPPOM MUI Harus Diperkuat", Jur-nal Halal, No. 99 Th. XVI Tahun 2013, Jakarta: LPPOM MUI, hlm. 48

${ }^{5}$ Yusuf Qardhawi, Halal dan Haram dalam Islam, Era Intermedia, Surakarta, 2007, hlm.5

${ }^{6}$ Drs. H. Ahmad Tohaputra, Alqur'an dan Terjemahannya, (Departemen Agama Republik Indonesia, 1984). 
hal-hal baik selanjutnya dalam ayat tersebut dijadikan sebagai suatu seruan kepada mereka yang beriman agar supaya imannya terpelihara. Kemudian pada ayat tersebut kepada Rosul-Rosul utusan Tuhan, diserukan pula agar jika tidak dalam keadaan terpaksa sebaiknya memperhatikan apa yang dikonsumsi dan dinikmatinya.

Pada waktu itu diadakannya Rukhshah yaitu keizinan memakan yang terlarang itu, yaitu semata-mata karena mempertahankan nyawa. Malahan kalau tidak dimakan sehingga membawa kematian karena lapar. Dihukumlah oleh agama sebagai orang yang menyia-nyiakan nyawa dan lagi tidak melampaui batas. Artinya jika sudah hilang lapar segeralah hentikan dan jangan dimakan lagi. Sesungguhnya Allah adalah Maha Pengampun atas seseorang yang terpaksa karena itu lalu memakannya, dan Maha Penyayang karena saying kepada hambanya tidak suka Allah hambanya itu mati kelaparan padahal jalan untuk mempertahankan hidup masih ada. Disinilah kita mendapat pedoman bahwasanya sekeras-kerasnya hukum namun pengecualian mesti ada. $^{7}$

Bahwa sertifikasi halal semula bersifat sukarela , artinya sertifikasi halal dilakukan oleh produsen dengan kesadarannya sendiri semata- mata untuk kepentingan memperoleh kepercayaan dari masyarakat konsumen. Tidak ada satu ketentuan undangundangpun yang mengatur tentang kewajiban bersertifikasi halal bagi produk yang beredar. Maka penyelenggaraan sertifikasi halal juga dilakukan oleh lembaga masyarakat seperti Majelis Ulama Indonesia yang membentuk badan sertifikasi halal yaitu Lembaga Pengkajian Pangan Obat dan Makanan. Oleh karena itu, hadirnya Undang-Undang Jaminan Produk Halal merepresentasikan tanggungjawab Negara, khususnya terhadap umat Islam, untuk melindungi dan memberikan rasa tenang dan aman dalam mengkonsumsi / menggunakan produk yang sesuai syariat yakni halal dan thoyib. Selanjutnya negara menganggap perlu sertifikasi halal itu dilakukan oleh sebuah badan dibawah Kementerian Agama, sehingga setelah melalui pembahasan di Dewan Perwakilan Rakyat selama 10 tahun, barulah Rancangan Undang-Undang Jaminan Produk Halal disahkan menjadi Undang-Undang Nomor 33 Tahun 2014 tentang Jaminan Produk Halal . Terbitnya undang- undang ini merubah sistem sertifikasi halal dari sukarela menjadi wajib . Maka pasca undang-undang ini diberlakukan semua produk yang beredar dan diperdagangkan di wilayah Indonesia wajib bersertifikat halal. Inilah

7 Prof. Dr. Haji Abdulmalik Abdulkarim Amrullah, Tafsir Al-Az̧har Juz 1 mengenai surat Al Baqarah ayat 173 , h. 387 
yang mendasari Peneliti ingin mengemukakan mengapa terjadinya perubahan sistem sertifikasi halal dari sukarela menjadi wajib. Perubahan sistem sertifikasi halal dari sukarela menjadi wajib menimbulkan akibat hukum berupa tanggung jawab yang harus di emban oleh negara sebagai konsekuensi negara mengatur maka negara juga harus mengambil peran sebagai tanggung jawab, sehingga pengaturan itu tidak menimbulkan kesewenang-wenangan atau abuse of power. Agar sertifikasi halal yang bersifat mandatory tidak merupakan pengaturan yang hanya membebani tanggung jawab kepada masyarakat, produsen dan pelaku usaha, maka diperlukan satu pengaturan dalam bentuk undang-undang yang mengatur bagaimana pengaturan sertifikasi halal yang ideal dalam sistem hukum Indonesia. Sejauh ini Indonesia tidak memiliki satu ketentuan khusus dalam bentuk undang-undang yang mengatur secara khusus mengenai sistem jaminan produk halal. Kepastian mengenai produk halal merupakan hal yang sangat penting bagi umat islam. Bahaya yang dimaksudkan dalam kategori halal itu berimplikasi pada ketenangan jiwa dan keyakinan konsumen muslim yang berdampak pada kepercayaan konsumen terhadap produk tersebut. Menyikapi hal ini, Majelis Ulama Indonesia melalui Lembaga Pengkajian Pangan, Obat-obatan dan Kosmetika dan Komisi Fatwa telah berikhtiar untuk memberikan jaminan produk makanan halal bagi konsumen muslim melalui instrumen ser-tifikat halal. Sertifikat halal merupakan fatwa tertulis Majelis Ulama Indonesia yang menyata-kan kehalalan suatu produk. Sertifikat halal se-lain sebagai perlindungan konsumen dari berba-gai macam makanan yang dianggap tidak layak sesuai syari'at Islam khusunya Indonesia yang mayoritas beragama Islam, juga mendorong kompetisi dan menjadi keunggulan.

Sertifikat halal saat ini menjadi salah satu poin untuk daya saing di perdagangan internasional. Pemerintah telah merespon pentingnya sertifikasi halal dan pencantuman tanda/label halal pada produk melalui be-berapa regulasi. Sehingga dari hal tersebut tujuan dari penyelenggaraan jaminan produk halal diharapkan mampu memberikan kepastian bagi konsumen muslim. Indonesia sebagai negara berpenduduk muslim terbesar di dunia akan menjadi penting terkait pengaturan mengenai jaminan produk halal dan non halal sehingga dengan demikian perlunya diatur mengenai kedua hal tersebut apalagi dengan terbukanya perdagangan bebas produk-produk olahan pangan dari negara lain akan beredar dengan leluasa di Indonesia. Sehingga dari uraian diatas sudah adanya pengaturan dasar dalam Undang-Undang Nomor 33 Tahun 2014 Tentang Jaminan Produk Halal, akan menjadi sangat menarik dibahas jika Indonesia sebagai 
Negara muslim terbesar di dunia seharusnya produk yang beredar yang berasal dari internal didominasi oleh produk-produk halal, namun faktanya lisensi produk halal yang diterapkan dalam sertifikasi makanan, sehingga jika kita melihat pada tujuannya seharusnya hal tersebut kurang tepat penggunaannya karena produk non halal yang beredar lebih sedikit dibandingkan produk halal. Disinilah kemungkinan terjadinya perubahan makanan yang semula halal menjadi tidak halal, yaitu jika bahan tambahan berasal dari ekstraksi hewan yang tidak halal. Dalam perkembangan IPTEK dan teknologi pengolahan pangan, keaslian dan kehalalan produk banyak berubah dan sulit untuk dideteksi, maka mutlak diperlukan sertifikasi halal. Ketentuan halal-haram adalah masalah krusial bagi konsumen Muslim, perlindungan kepada masyarakat atas produk makanan, minuman, obat-obatan, kosmetika, dan barang gunaan salah satunya melalui Sertifikasi Halal sebagai salah satu bentuk perlindungan konsumen dan tanggung jawab negara. Label halal menjadi kunci pokok bagi masyarakat untuk memutuskan pilihan untuk membeli atau tidak terhadap suatu produk. Mengkonsumsi produk halal menurut keyakinan agama islam dilakukan demi kualitas hidup yang lebih baik serta merupakan hak warga negara yang dijamin oleh Undang-Undang Dasar 1945. Dengan demikian, mengkonsumsi produk halal menjadi persoalan sosial di masyarakat sekaligus menjadi tanggung jawab negara dengan basis pemikiran yang sama, yakni terjaminnya kesediaan produk halal. Kejujuran produsen, kewaspadaan konsumen, serta regulasi yang baik merupakan kesatuan integral dalam penegakan hukum mengenai ketersediaan produk halal. Salah satu masalah produk halal adalah mengenai sertifikasi halal yang bertujuan untuk melindungi masyarakat dari mengkonsumsi produk yang tidak jelas kehalalannya, apalagi produk yang diharamkan dapat merusak nilai ibadah dan membahayakan kesehatan. Peraturan Pemerintah Republik Indonesia Nomor 69 tahun 1999 tentang Label dan Iklan Pangan Pasal 1 ayat menyebutkan, Pangan halal adalah pangan yang tidak mengandung unsur atau bahan yang haram atau dilarang untuk dikonsumsi umat Islam, baik yang menyangkut bahan baku pangan, bahan tambahan pangan, bahan bantu dan bahan penolong lainnya termasuk bahan pangan yang diolah melalui proses rekayasa genetika dan iradiasi pangan, dan yang pengelolaannya dilakukan sesuai dengan ketentuan hukum agama Islam. Di Indonesia, secara normatif produk halal di atur dalam Undang-Undang Nomor 33 Tahun 2014 tentang Jaminan Produk Halal . Dalam pasal 1 ayat dinyatakan bahwa, Produk Halal adalah produk yang telah dinyatakan halal sesuai dengan syariat islam. Sedangkan yang dimaksud Jaminan Produk Halal menurut 
ketentuan Pasal 1 ayat UU JPH di atur bahwa, (Kepastian hukum terhadap kehalalan suatu produk yang dibuktikan dengan Sertifikat Halal). Maksud dari ketentuan dalam Pasal 1 ayat dan tersebut adalah bahwa, produk yang telah dinyatakan halal sesuai dengan syariat islam harus dibuktikan dengan Sertifikat Halal yang dikeluarkan oleh Badan Penyelenggara Jaminan Produk Halal, berdasarkan fatwa halal tertulis yang dikeluarkan oleh Majelis Ulama Indonesia sebagaimana dimaksud Pasal 1 ayat UU JPH. Sementara belum terbentuknya BPJPH sertifikasi terhadap produk halal dilakukan oleh Majelis Ulama Indonesia melalui Lembaga Pengkajian Pangan, Obat-obatan dan Kosmetika Majelis Ulama Indonesia, hal ini sejalan dengan Pasal 60 UU JPH yang menyebutkan bahwa, MUI tetap menjalankan tugasnya di bidang Sertifikasi Halal sampai dengan BPJPH dibentuk.

\section{B. Telaah Konsep}

Adapun cara yang digunakan untuk mengambil hasil penelitian normatif agar menjadi lebih faktual dalam penjelasannya, maka diperlukan pendekatan hukum yang dilakukan dalam setiap pembahasannya, pendekatan-pendekatan hukum yang dilakukan diharapkan mampu menentukan nilai dari hasil penelitian tersebut. Pendekatan yang digunakan dalam penelitian ini menggunakan pendekatan perundang-undangan (statute approach) karena peneliti menganggap adanya norma hukum yang kabur (vage normen). Pendekatan perbandingan yang Penelitian perbandingan dilakukan untuk membandingkan antara sistem hukum yang berbeda, dengan tidak membandingkan antara konsep hukum dalam suatu negara. Pendekatan historis dilakukan dengan melakukan penafsiran terhadap aturan perundang-undangan, dan penafsiran pada saat pembentukannya.Penelitian historis dilakukan untuk memperdalam maksud dan makna penyusunan suatu hukum dan memberikan pemahaman menurut peneliti. Pendekatan filsafat untuk menyelami isu hukum dalam konsep mengenai ajaran hukum dari segi filosofis. dan pendekatan konseptual (conceptual approach).

\section{Metode Penelitian}

Penelitian hukum normatif preskriptif merupakan suatu proses untuk menemukan tujuan hukum, nilai-nilai keadilan, validitas aturan hukum, konsep-konsep hukum dan norma-norma hukum. Kemudian sebagai ilmu terapan, ilmu hukum menetapkan standar prosedur, ketentuan-ketentuan, rambu-rambu dalam melaksanakan aturan hukum. Penelitian hukum normatif dalam disertasi ini ditujukan untuk memberikan penjelasan secara sistematis terkait sertifikasi dan labelisasi halal dalam 
perlindungan dan jaminan kepastian hukum produk pangan halal bagi konsumen muslim di Indonesia. Metode penelitian normatif ini dilakukan dengan cara menarik asas hukum yang ada pada hukum positif tertulis dan dilakukan penelitian terhadap pengertian dasar sistematik hukum mengenai peristiwa hukum atau hubungan hukum yang terjadi dalam masyarakat dikaitkan Undang-Undang yang berlaku untuk peristiwa hukum tersebut kemudian dilakukan taraf sinkronisasi peraturan perundang-undangan yang terkait dengan bahan-bahan kepustakaan untuk mencari informasi dan membuat kesimpulan dalam permasalahan yang diteliti. Penelitian ini dilakukan untuk menghasilkan argumentasi, teori, atau konsep baru sebagai predisertasi dalam penyelesaian masalah yang dihadapi. ${ }^{8}$

\section{Pembahasan}

Salah satu tujuan pengaturan, pembinaan, dan pengawasan pangan adalah terciptanya perdagangan pangan yang jujur dan bertanggung jawab76, sebagaimana dikehendaki oleh Undang-Undang Nomor 7 Tahun 1996 Tentang Pangan. Salah satu upaya untuk mencapai tertib pengaturan di bidang pangan adalah melalui pengaturan di bidang label dan iklan pangan, yang dalam prakteknya selama ini belum memperoleh pengaturan sebagaimana mestinya.?

Masyarakat berhak untuk memperoleh informasi yang benar dan tidak menyesatkan mengenai pangan yang akan dikonsumsinya, khususnya yang disampaikan melalui label dan iklan pangan ${ }^{10}$. Dalam hubungannya dengan masalah label dan iklan pangan maka masyarakat perlu memperoleh informasi yang benar, jelas dan lengkap mengenai kuantitas, isi (volume), kualitas maupun hal-hal lain yang diperlukan, termasuk komposisi dari produk kemasan pangan yang beredar di pasaran. Informasi pada label pangan atau melalui iklan sangat diperlukan bagi masyarakat agar supaya masing-masing individu secara tepat dapat menentukan pilihan sebelum membeli atau mengkonsumsi pangan. Tanpa adanya informasi yang jelas maka kecurangan-kecurangan dapat terjadi ${ }^{11}$.

Banyaknya pangan yang beredar di masyarakat tanpa mengindahkan ketentuan tentang pencantuman label dinilai sudah meresahkan. Tidak hanya masalah yang berhubungan dengan kesehatan saja yang perlu diinformasikan secara benar dan

\footnotetext{
${ }^{8}$ Peter Mahmud Marzuki, Penelitian Hukum, Prenada Media, Jakarta, 2006, h.26.

${ }^{9}$ Penjelasan Umum Peraturan Pemerintah tentang Label dan Iklan Pangan

${ }^{10}$ Konsiderans huruf c Peraturan Pemerintah tentang Label dan Iklan Pangan

${ }^{11}$ Penjelasan Umum Peraturan Pemerintah tentang Label dan Iklan Pangan
} 
tidak menyesatkan melalui label dan atau iklan pangan, namun perlindungan secara batiniah perlu diberikan kepada masyarakat. Masyarakat Islam merupakan jumlah terbesar dari penduduk Indonesia yang secara khusus dan non diskriminatif perlu dilindungi melalui pengaturan halal. Bagaimanapun juga, kepentingan agama atau kepercayaan lainnya tetap dilindungi melalui tanggung jawab pihak yang memproduksi pangan atau memasukkan pangan ke dalam wilayah Indonesia untuk diperdagangkan bagi keperluan tersebut. ${ }^{12}$

Bahwa ketentuan tersebut merupakan cikal bakal mengenai perlindungan negara kepada warga negara dalam kata lain merupakan jaminan konstitusi, akan tetapi mengingat ketentuan ini masih sebatas peraturan pemerintah maka badan legislatif menganggap perlu adanya undang-undang yang mengatur secara khusus mengenai produk halal.

Banyaknya pangan yang beredar di masyarakat tanpa mengindahkan ketentuan tentang pencantuman label dinilai sudah meresahkan. Bagaimanapun juga, kepentingan agama atau kepercayaan lainnya tetap dilindungi melalui tanggung jawab pihak yang memproduksi pangan atau memasukkan pangan ke dalam wilayah Indonesia untuk diperdagangkan bagi keperluan tersebut. ${ }^{13}$

Dalam Pasal 1 ayat (5) PP Nomor 69 Tahun 1999 tentang Label dan Iklan Pangan terdapat definisi dari pangan halal, yaitu pangan yang tidak mengandung unsur atau bahan yang haram atau dilarang untuk dikonsumsi umat Islam, baik yang menyangkut bahan baku pangan, bahan tambahan pangan, bahan bantu dan bahan penolong lainnya termasuk bahan pangan yang diolah melalui proses rekayasa genetika dan iradiasi pangan, dan yang pengelolaannya dilakukan sesuai dengan ketentuan hukum agama Islam.

Kata 'halal' saat ini menjadi kata yang seksi, mendunia baik di negara Muslim maupun non-Muslim seiring dengan pesatnya bisnis-bisnis yang berbasiskan syariah. Kata 'halal' berasal dari kata Arab halla, yahillu, hillan, yang berarti membebaskan, melepaskan, memecahkan, membubarkan, dan membolehkan. Berdasarkan pengertian di atas kata 'halal' bisa dipahami sebagai (1) segala sesuatu yang menyebabkan seseorang tidak dihukum jika menggunakannya; (2) sesuatu yang boleh dikerjakan menurut syarak (Lihat: Aziz dkk, Eksiklopedi Hukum Islam Jilid 2, 2006). Berdasarkan

\footnotetext{
12 Penjelasan Umum PP Nomor 69 Tahun 1999.

${ }^{13}$ Penjelasan Umum PP Nomor 69 Tahun 1999
} 
pengertian di atas dapat dipahami bahwa kata 'halal' dihubungkan dengan kebolehan untuk mengkonsumsi atau menggunakan berbagi macam benda untuk keperluan fisik, baik berupa makanan, obat-obatan, tumbuh-tumbuhan dan lain-lain.

Muslim yang taat tentunya sangat menjaga kehalalan produk yang dikonsumsinya. Hal ini menandakan kepatuhan dirinya atas ajaran agama yang memang telah mengatur hal tersebut secara jelas. Oleh karena itu, penting bagi umat Muslim jaminan kehalalan produk yang dikonsumsinya. Saat ini telah banyak produk yang beredar, namun tidak semua produk tersebut halal untuk dikonsumsi. Hal ini bisa saja disebabkan proses atau bahan untuk membuatnya terdiri dari berbagai unsur yang diharamkan. Ada banyak kasus tentang hal produk halal, sebagai contoh: di tahun 80an dan 90-an pernah terdengar ada produk pelezat makanan dan beberapa biskuit yang diragukan kehalalannya karena ditengarai salah satu bahan bakunya dicampur dengan lemak babi atau alkholol. Kondisi tersebut di atas tentu sangat meresahkan umat Islam, terutama di Indonesia yang mayoritas penduduknya beragama Islam. Oleh karena produk tidak semua produk yang beredar di masyarakat dijamin dan disertifikasi kehalalannya, maka dari itu hal ini perlu diatur secara jelas sehingga tidak menimbulkan keraguan dan keresahan dalam masyarakat.

Di Indonesia untuk menjamin kehalalan suatu produk, pada 2014 pemerintah bersama dengan Dewan Perwakilan Rakyat mengesahkan Undang-undang Nomor 33 Tahun 2014 tentang Jaminan Produk Halal (selanjutnya disingkat UU-JPH). Diundang-undangkannya UU-JPH ini bertujuan untuk memberikan kenyamanan, keamanan, keselamatan, dan kepastian ketersediaan produk halal bagi masyarakat dalam mengonsumsi dan menggunakan produk, serta meningkatkan nilai tamah bagi pelaku usaha untuk memproduksi dan menjual produk halal (Lihat penjelasan atas UU $\mathrm{JPH})$.

Menurut UU-JPH, yang dimaksud dengan produk adalah: barang dan/atau jasa yang terkait dengan dengan makanan, minuman, obat, kosmetik, produk kimiawi, produk biologi, produk rekayasa genetik, serta barang gunaan yang dipakai, digunakan, atau dimanfaatkan oleh masyarakat (lihat: Pasal 1 UU-JPH). Semua produk yang telah ditetapkan sebagaimana diatur pada Pasal 1 mesti dijamin kehalalannya. Islam mengajarkan bahwa suatu produk dinyatakan halal jika telah sesuai dengan syariat Islam. Dengan kata lain, produk tersebut tidak mengandung bahan-bahan yang 
diharamkan menurut ajaran Islam, seperti alkohol, babi, bangkai, darah, dan hewan yang tidak disembelih tidak sesuai dengan syariat Islam.

Lalu pertanyaan yang muncul adalah lembaga apa yang berwenang menyatakan kehalalan suatu produk? Menurut UU-JPH, lembaga yang berwenang menyelenggarakan jaminan produk halal adalah Badan Penyelenggara Jaminan Produk Halal (BPJPH), yang mana badan ini dibentuk oleh Menteri Agama. BPJPH berwenang untuk: (a) merumuskan dan menetapkan kebijakan jaminan produk halal (JPH); (b) menetapkan norma, standar, prosedur, dan kriteria JPH; (c) menerbitkan dan mencabut Sertifkat Halal dan Label Halal pada Produk; (d) melakukan registrasi Sertifikat Halal pada Produk luar negeri; (e) melakukan sosialisasi, edukasi dan publikasi Produk Halal; (f) melakukan akreditasi terhadap Lembaga Penjamin Halal (LPH); (g) melakukan registrasi Auditor Halal; (h) melakukan pengawasan terhadap JPH; (i) melakukan pembinaan Auditor Halal; dan (j) melakukan kerja sama dengan lembaga dalam dan luar negeri di bidang penyelengaraan JPH (lihat: Pasal 6 UU JPH).

Dalam melakukan pemeriksaan dan/atau pengujian kehalalan produk, BPJPH bekerjasama dengan Lembaga Penjamin Halal (LPH). Di sini LPH adalah sebuah lembaga yang dibentuk oleh pemerintah dan/atau masyarakat; sedangkan dalam melakukan sertifikasi, auditor halal menetapkan kehalalan suatu produk dan akreditasi Lembaga Penjamin Halal. Badan Penyelenggara Jaminan Produk Halal tidak hanya menjalin kerjasama dengan Majelis Ulama Indonesia (MUI), tetapi juga melakukan koordinasi dengan berbagai instasi/lembaga terkait seperti Kementerian Perindustrian, Kementerian Perdagangan, Kementerian Kesehatan.

Kenyatannya, hingga saat ini BPJPH belum dibentuk oleh Kementerian Agama, padahal UU-JPH mensyaratkan berdirinya BPJPH paling lambat 3 tahun semenjak UU-JPH diundangkan. BPJPH merupakan garda terdepan dalam penyelenggaraan JPH, oleh karena itu, urgensi pembentukkannya menjadi tinggi. Berhubung BPJPH belum dibentuk, maka peran sertifkasi produk halal masih tetap dijalankan oleh MUI. Begitu juga halnya dengan Peraturan Pelaksana (PP) UU-JPH yang sampai saat ini belum juga diterbitkan. Padalah dalam undang-undang ditetapkan secara tegas bahwa peraturan pelaksana UU-JPH selambat-lambatnya harus terbit dua tahun sejak UU-JPH diundangkan. Faktanya sampai saat ini belum ada peraturan pelaksana yang dikeluarkan. Oleh sebab itu, pengaturan halal bisa dikatakan berjalan tidak maksimal dan tidak memberikan kepastian hukum bagi para penyedia produk 
halal dan konsumen muslim sebagai end-user. Pemerintah, khususnya Kementerian Agama, harus konsisten dan sungguh-sungguh dalam menjalankan amanat yang telah ditetapkan UU-JPH . BPJPH dan peraturan pelaksana UU-JPH harus dipersiapkan jauh-jauh hari sehingga tidak terkesan lahir secara permatur. Sosialisasi UU-JPH juga harus tetap dilakukan secara terus-menerus oleh Kementerian Agama kepada seluruh elemen masyarakat, baik kepada produsen maupun konsumen. Dengan demikian, pentingnya keberadaan sertifikasi halal atas produk yang dipasarkan dan dikonsumsi dapat diketahui oleh masyarakat luas.

Pada prinsipnya,peraturan pemerintah mengenai label dan iklan pangan ini mensyaratkan setiap orang yang memproduksi atau memasukkan pangan yang dikemas ke dalam wilayah Indonesia untuk diperdagangkan wajib mencatumkan label pada, di dalam, dan atau di kemasan pangan. Pencantuman label tersebut dilakukan sedemikian rupa sehingga tidak mudah lepas dari kemasannya, tidak mudah luntur atau rusak, serta tercetak pada bagian kemasan pangan yang mudah dilihat dan dibaca hal tersebut terdapay dalam Pasal 2 ayat (1) dan ayat (2) P Nomor 69 Tahun 1999 tentang Label dan Iklan Pangan.

Setiap orang yang memproduksi atau memasukkan pangan yang dikemas ke dalam wilayah Indonesia utuk diperdagangkan, dilarang mencatumkna label yang tidak memenuhi ketentuan PP Nomor 69 Tahun 1999 tentang Label dan Iklan Pangan ini. Terkait dengan pernyataan halal pada kemasan pangan, Pasal 10 PP Nomor 69 Tahun 1999 tentang Label dan Iklan Pangan mengatur bahwa, "Setiap orang yang memproduksi atau memasukkan pangan yang dikemas ke dalam wilayah Indonesia utuk diperdagangkan dan menyatakan bahwa pangan tersebut halal bagi umat Islam, bertanggung jawab atas kebenaran pernyataan tersebut dan wajib mencatumkan keterangan atau tulisan halal pada label."

Lebih lanjut pasal ini dijelaskan dalam Pasal 11 ayat (2) PP Nomor 69 Tahun 1999 yang menyatakan bahwa "Masalah pemeriksaan halal ditetapkan oleh Departemen Agama serta Majelis Ulama Indonesia (MUI)". Dari penjelasan kedua pasal diatas, dapat dijelaskan bahwa pencantuman label halal pada kemasan suatu produk bukan atas dasar pertimbangan pelaku usaha. Masalah halal adalah wewenang Majelis Ulama Indonesia (MUI).

\section{E. Penutup}


Bahwa Sertifikasi Halal yang (selama ini) telah dilakukan oleh Majelis Ulama Indonesia (MUI) melalui LPPOM MUI dan Komisi Fatwa. Adapun kegiatan Labelisasi Halal dikelola oleh Badan POM sudah sangat tepat dan memberikan jaminan perlindungan dan kepastian hukum produk pangan halal karena sudah melalui proses yang panjang antara lain adanya sistem jaminan halal oleh perusahaan, audit oleh LPPOM dan Komisi fatwa.

Permasalahan timbul ketika Undang-Undang Nomor 8 Tahun 1999 tentang Perlindungan Konsumen, Undang-Undang Republik Indonesia Nomor 18 Tahun 2012 tentang Pangan dan Pe-raturan Pemerintah Republik Indonesia Nomor 69 Tahun 1999 tentang Label dan Iklan Pangan tidak menjadikan sertifikasi dan labelisasi halal sebagai sebuah bentuk kewajiban (mandotary) bagi pelaku usaha, tetapi bersifat sukarela (voluntary). Maka sertifikasi halal dan labelisasi halal dapat dikatakan belum mempunyai legitimasi hukum yang kuat, sehingga tidak memberikan perlindungan dan kepastian hukum produk pangan halal bagi konsumen.

\section{DAFTAR PUSTAKA}

Amin, Ma'ruf. "Halal Berlaku Untuk Seluruh Umat”. Jurnal Halal . No. 101 Th. XVI 2013, Jakarta: LPPOM MUI;

. "Fatwa Halal Melndungi Umat dari Ke-rugian yang Lebih Besar", Jurnal Halal, No. 103 Th. XVI 2013, Jakarta: LPPOM MUI;

------. "Islam Menghalalkan yang Baik dan Mengharamkan yang Buruk". Jurnal Ha-lal. No. 104 Th. XVI 2013. Jakarta: LPPOM MUI;

Apriyantono, Anton. 'LPPOM MUI Harus Diper-kuat'. Jurnal Halal. No. 99 Th. XVI 2013. Jakarta: LPPOM MUI;

Arintawati, Muti. "Hati-hati Memilih Bahan Pe-warna”. Jurnal Halal. No. 94 Th. XV 2012. Jakarta: LPPOM MUI;

Attamimi, A. Hamid S. “Aktualisasi Hukum Is-lam”. Jurnal Mimbar Hukum. No. 13 Thn V Tahun 1994. Jakarta: Ditbinbapera;

Abdul Kholik, SH. M.Si, Pengujian Undang-Undang Nomor 33 Tabun 2014 Tentang Jaminan Produk Halal, Keterangan Ahli yang disampaikan pada Sidang Perkara Nomor 5/PUU-XV/2017 Perihal Pengujian Undang- Undang Nomor 33 Tahun 2014 Tentang Jaminan Produk Halal Terhadap Undang-Undang Dasar Negara Republik Indonesia Tahun 1945 pada tanggal 20 Juli 2017, 2017

Abdul Rohman dan Yuny Erwanto, URGENSI JAMINAN PRODUK HALAL, Pusat Penelitian Produk Halal, Universitas Gadjah Mada Yogyakarta, Indonesia, Keterangan Ahli yang disampaikan pada Sidang Perkara Nomor 5/PUU- XV/2017 Perihal Pengujian Undang-Undang Nomor 33 Tahun 2014 Tentang Jaminan 
Teddy Prima Anggriawan: Perlindungan Konsumen Pangan Pada Negara Mayoritas Muslim...

Produk Halal Terhadap Undang-Undang Dasar Negara Republik Indonesia Tahun 1945 pada tanggal 20 Juli 2017Putusan Mahkamah Konstitusi Republik Indonesia Nomor 2/PUU-IX/2011

Abdullah Ikhsan, Strategi Merebut Pasar MEA dengan Produk Halal, Press Release yang disampaikan dalam Diskusi Publik Indonesia Halal Watch tanggal 29 Desember 2015.

Ali Ahmad. Menguak Teori Hukum (Legal Theory) dan Teori Peradilan (Juridical Prudence) termasuk. interpretasi Undang-Undang (Legisprudence). Vol. 1 Pemahaman awal. (Jakarta: Penerbit Kencana). 2009.

ErwinMuh., Filsafat Hukum ; Refleksi Kritis Terhadap Hukum, Jakarta : Rajawali Press, 2011,

M Tambrin, Implementasi Undang-Undang Nomor 33 Tabun 2014 Tentang Jaminan Produk Halal, disampaikan pada Acara Temu Wicara dengan Perkosmi tanggal 28 Juni 2016

Mangunhardjana A. 1997. Isme-isme dalam Etika dari A sampai Z. (Jogjakarta: Kanisius)

RasjidiLili, Dasar-Dasar Filasafat Hukum, Citra Aditya Bakti, Bandung 1996

Sakti Muthia, Dwi Aryanti R, Yuliana Yuli W. Perlindungan konsumen terhadap beredarnya Makanan Yang Tidak bersertifikat halal, Jurnal Yuridis Vol.2 No.1 Juni 2015:62-72, FH UPN “Veteran” Jakarta ISSN 1693448

SoekantoSoerjono, Kesadaran Hukum dan Kepatuban Hukum, CV Rajawali, Jakarta, 1982

Stuart Mill John Utilitarianism. (London: Longmans, Green, Reader, and Dyer, 1871), hlm. 107. 